\title{
Cytogenetic study of the giant otter Pteronura brasiliensis Zimmermann 1780 (Carnivora, Mustelidae, Lutrinae)
}

\author{
Jorge Felipe Oliveira Franco-de-Sá ${ }^{1}$, Fernando César Weber Rosas ${ }^{2}$ and Eliana Feldberg ${ }^{2}$ \\ ${ }^{1}$ Instituto de Ciências Biológicas, Universidade Federal do Amazonas, Manaus, AM, Brazil. \\ ${ }^{2}$ Instituto Nacional de Pesquisas da Amazônia, Coordenação de Pesquisas em Biologia Aquática, \\ Manaus, AM, Brazil.
}

\begin{abstract}
The giant otter, Pteronura brasiliensis Zimmermann 1780 (Carnivora, Mustelidae, Lutrinae), was widely distributed in South America but stable populations are now only found in the Pantanal and Amazon regions and the species is classified as endangered. There is only one recognized species of giant otter, although two subspecies of doubtful value have also been cited in the literature. We present the first karyotype of four captive $P$. brasiliensis specimens, all of which posses $2 n=38$ chromosomes as $14 M+8 S M+6 S T+8 A$ and one pair of sexual chromosomes. An heteromorphic secondary constriction, associated with the nucleolar organizer region (NOR), was seen on the long arms of chromosome pair 17 . The $\mathrm{C}$-banding technique revealed heterochromatin in the centromeric region of all the chromosomes and the NOR was C-banding positive. The giant otter presented the same diploid number as most mustelids, although its karyotype is quite species-specific.
\end{abstract}

Key words: Amazon, aquatic mammals, ariranha, karyotype.

Received: January 9, 2007; Accepted: February 7, 2007.

There are five Amazonian aquatic mammals, the Amazonian manatee (Trichechus inunguis), the pink dolphin (Inia geoffrensis), the tucuxi (Sotalia fluviatilis), the Neotropical otter (Lontra longicaudis) and the giant otter (Pteronura brasiliensis). The World Conservation Union (IUCN) classifies the Amazonian manatee and the pink dolphin as vulnerable and the tucuxi and the neotropical otter as belonging to the "data deficient" category, while the giant otter is classified as an endangered species (IUCN, 2006).

Riverine habitats are highly vulnerable to anthropogenic activities, this being especially true in the Amazon basin, which is suffering rapid development leading to degradation and loss of essential habitats for giant otters (Borobia and Rosas, 1991; Rosas, 1994; Carter and Rosas, 1997).

The giant otter, Pteronura brasiliensis Zimmermann 1780 (Carnivora, Mustelidae, Lutrinae), is the largest of all otters and is endemic to South America, with historical records of sightings from north to south-central South America. However, currently stable populations are limited to the Amazon basin and upper Pantanal in the ParanáParaguay river basin (Carter and Rosas, 1997). Two $P$.

Send correspondence to Eliana Feldberg. Instituto Nacional de Pesquisas da Amazônia, Coordenação de Pesquisas em Biologia Aquática, Caixa Postal 478, 69011-970 Manaus, AM, Brazil. E-mail: feldberg@inpa.gov.br. brasiliensis subspecies have been cited in the literature but are of doubtful value (Duplaix, 1980).

Karyotypic studies have been carried out to analyze intra- and interspecific and intra- and interpopulation variations as well as to identify cryptic species, mutagenic effects and to solve taxonomic problems (Guerra, 1988; Macgregor, 1993). Nie et al. (2002) used chromosomal rearrangements, a rare type of genomic change, to investigate some systematic questions relating to the genome phylogeny of the domestic cat, red panda and five mustelid species. However, while cytogenetic studies have previously been carried out on other mustelid species (Freitas et al., 1975; Kurose et al., 2000; Graphodatsky et al., 2002) there have been no published studies on the chromosomal constitution of $P$. brasiliensis.

In this paper we describe for the first time the karyotype of $P$. brasiliensis, providing valuable data to verify the validity of the alleged subspecies in future studies using specimens from the Pantanal region.

We carried out chromosomal analyses on two male and two female giant otters from the Brazilian Amazon basin held in captivity at the Aquatic Mammals Laboratory of the National Institute for Amazonian Research (Instituto Nacional de Pesquisas da Amazônia, INPA), Manaus, Amazonas, Brazil (Figure 1). The giant otters were sedated with $1.93 \pm 0.57 \mathrm{mg} \mathrm{kg}^{-1}$ of Zoletil ${ }^{\circledR}$ (Virbac, Brazil) and 


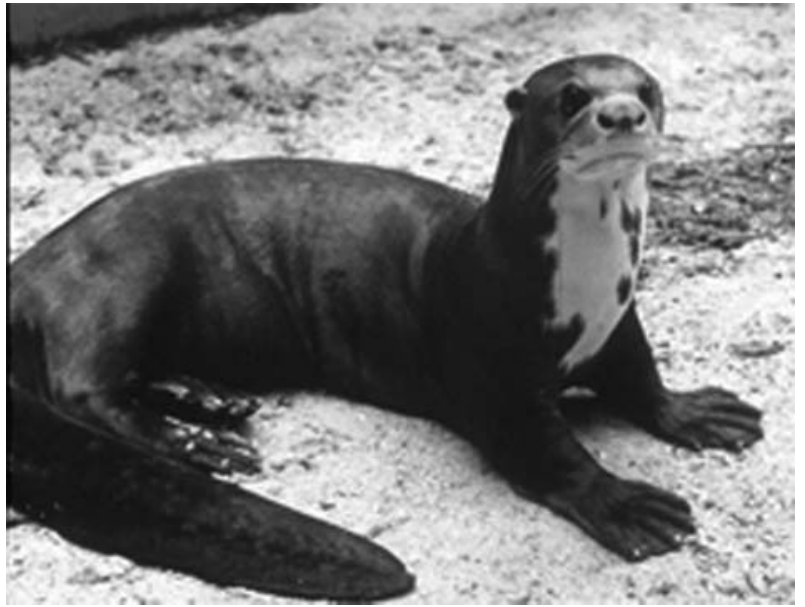

Figure 1 - Amazonian giant otter (Pteronura brasiliensis) held in captivity at the Aquatic Mammals Laboratory of the Brazilian National Institute for Amazonian Research (Instituto Nacional de Pesquisas da Amazônia, INPA), Manaus, Amazonas (AM), Brazil.

blood samples collected from the femoral vein using an heparinized syringe which was maintained in a vertical position for $30 \mathrm{~min}$ after collection to allow the lymphocytes to separate. After separation, the lymphocyte layer was added to Complete Medium for Karyotyping (Cultilab, Campinas, SP) and the cultures incubated for $72 \mathrm{~h}$ at $37^{\circ} \mathrm{C}$. One hour before the end of incubation, $0.3 \mathrm{~mL}$ of colchicine at $0.0125 \%(\mathrm{w} / \mathrm{v})$ was added. The cells were harvested by centrifugation at $1000 \mathrm{rpm}$ for $10 \mathrm{~min}$ and $10 \mathrm{~mL}$ of hypotonic $0.075 \mathrm{M} \mathrm{KCl}$ solution at $37{ }^{\circ} \mathrm{C}$ was progressively added in $2 \mathrm{~mL}$ aliquots at $10 \mathrm{~min}$ intervals, after which the cells were fixed using four changes of Carnoy fluid (methanol/acetic acid 3:1 v/v). The methodology was modified from the protocol described by Verma and Babu (1995). Constitutive heterochromatin was detected using Cbanding (Sumner, 1972) and the nucleolar organizer regions (NORs) by silver nitrate staining (Ag-NORs) as described by Howell and Black (1980). The chromosomes were identified by the arm ratio criteria (Levan et al., 1964) where the metacentric $(\mathrm{M})$, submetacentric (SM) and subtelocentric (ST) were considered as bi-armed chromosomes and the acrocentric (A) as one-armed chromosomes. In each group, the chromosomes were arranged in order of decreasing size.

The four giant otters examined showed a diploid number of 38 chromosomes, of which 36 were autosomes $(14$ metacentric +8 submetacentric +6 subtelocentric +8 acrocentric) and two were sex chromosomes (Figure 2a and b). The fundamental number of autosomes ( $\mathrm{FNa}$ ) was 64 . The C-banding technique identified positive centromeric heterochromatin in all the chromosomes, with chromosomes 8,10 and 13 also showing telomeric heterochromatin (Figure 2c). Chromosome pair 17 showed a nucleolar region which was $\mathrm{C}$-banding positive (Figure 2c) and cor- a

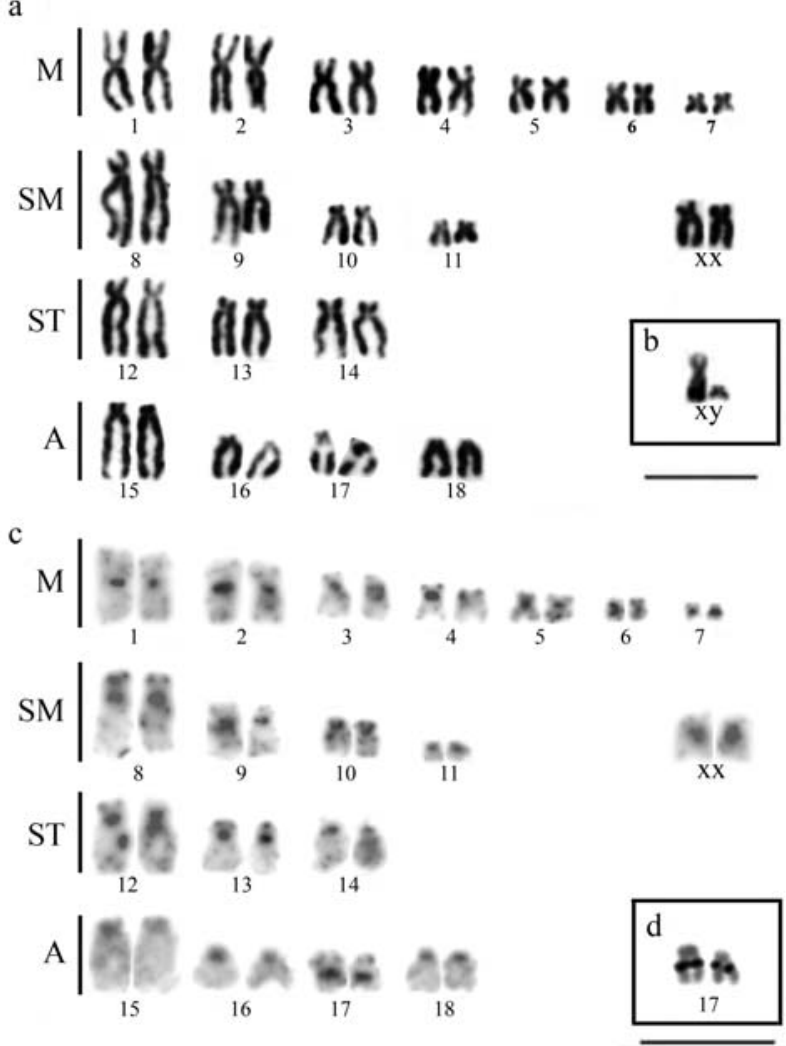

Figure 2 - Karyotype of Pteronura brasiliensis: (a) female and (b) sex chromosomes of male standard staining; (c) C-banding and (d) Nucleolar pair stained with silver nitrate $(\mathrm{Bar}=10 \mu \mathrm{m})$.

responded to a secondary constriction in the proximal region of the long arms of this chromosome (Figure 2d).

The diploid chromosome number in Mustelidae ranges from 30 in Mustela vison (Graphodatsky et al., 2000) to 44 in Mustela altaica (Graphodatsky et al., 1976), Mustela ermina orientalis and Mustela mustela anakuma (Obara, 1991). However, in more than $60 \%$ of mustelids the diploid number is $2 \mathrm{n}=38$ (Table 1). Although mustelid karyotypes are conserved in regard to diploid number they present considerable differences in chromosome structure, indicating that several rearrangements occurred during the evolution of this group (Couturier and Dutrillaux, 1986). Sex chromosomes also differ in morphology (M, SM, ST, A) and size (large, medium, small), but the Y chromosome is always the smallest.

According to Graphodatsky et al. (2002), the differentiation mustelid karyotypes from the common ancestor probably occurred by means of several chromosomal rearrangements (e.g. centric fusions and fissions, addition of heterochromatin, pericentric inversions) which caused the large karyotype variability observed in the Mustelidae family. Comparative analysis of the chromosomal segments in mustelids and out-group species revealed 18 putative conserved autosomal segments, which are probably ancestral chromosomes or chromosome arms (Graphodatsky et al., 2002). 
Table 1 - List of the chromosome number of 22 mustelid species.

\begin{tabular}{|c|c|c|c|c|c|c|}
\hline \multirow[b]{3}{*}{ Species } & \multicolumn{5}{|c|}{ Karyotype } & \multirow[b]{3}{*}{ Reference } \\
\hline & \multirow[b]{2}{*}{$\begin{array}{l}\text { Diploid number } \\
\text { (2n) }\end{array}$} & \multicolumn{2}{|c|}{ Autosomes } & \multicolumn{2}{|c|}{ Sex chromosomes } & \\
\hline & & $\begin{array}{c}\text { Number of autosomic } \\
\text { arms (FNa) }\end{array}$ & $\begin{array}{l}\text { Karyotype } \\
\text { formula }\end{array}$ & $\mathrm{X}$ & $\mathrm{Y}$ & \\
\hline Amblonyx cinerea & 38 & 64 & - & sm & $\mathrm{a}$ & $\begin{array}{l}\text { Couturier and } \\
\text { Dutrillaux, } 1986\end{array}$ \\
\hline Ictonyx striatus & 38 & - & - & - & - & $\begin{array}{l}\text { Graphodatsky et al., } \\
2002\end{array}$ \\
\hline Lontra longicaudis & 38 & 62 & $8 \mathrm{~m}+18 \mathrm{sm}+10 \mathrm{a}$ & sm & $\mathrm{sm}$ & Freitas et al., 1975 \\
\hline Martes foina & 38 & 68 & $6 \mathrm{~m}+28 \mathrm{sm}-\mathrm{st}+4 \mathrm{a}$ & - & - & Yigit et al., 1998 \\
\hline M. melampus melampus & 38 & 68 & $10 \mathrm{~m}+6 \mathrm{sm}+16 \mathrm{st}+4 \mathrm{a}$ & $\mathrm{m}$ & a & Obara, 1991 \\
\hline M. melampustsuensis & 38 & 68 & $10 \mathrm{~m}+6 \mathrm{sm}+16 \mathrm{st}+4 \mathrm{a}$ & $\mathrm{m}$ & $\mathrm{a}$ & Tsuchiya, 1979 \\
\hline M. zibellina brachyura & 38 & 66 & $10 \mathrm{~m}+6 \mathrm{sm}+14 \mathrm{st}+6 \mathrm{a}$ & $\mathrm{m}$ & $\mathrm{a}$ & Iwasa and Hosoda, 2002 \\
\hline M. flavigula & 40 & 68 & - & $\mathrm{m}$ & st & Nowak, 1991 \\
\hline Meles meles anakuma & 44 & 62 & $20 \mathrm{~m}-\mathrm{sm}-\mathrm{st}+22 \mathrm{a}$ & $\mathrm{m}$ & st & Obara, 1991 \\
\hline Melogale moschata & 38 & - & - & - & - & Nowak, 1991 \\
\hline Mustela vison & 30 & - & - & - & - & $\begin{array}{l}\text { Graphodatsky et al., } \\
2000\end{array}$ \\
\hline M. eversmanni & 38 & - & - & - & - & $\begin{array}{l}\text { Graphodatsky et al., } \\
1976\end{array}$ \\
\hline M. itatsi & 38 & 64 & $14 m+14 s m-s t+8 a$ & $\mathrm{sm}$ & $\mathrm{a}$ & Kurose et al., 2000 \\
\hline M. lutreola & 38 & 58 & - & sm & $\mathrm{m}$ & $\begin{array}{l}\text { Graphodatsky et al., } \\
1976\end{array}$ \\
\hline M. nivalis namiyei & 38 & 66 & $18 \mathrm{~m}+12 \mathrm{sm}-\mathrm{st}+6 \mathrm{a}$ & $\mathrm{m}$ & $\mathrm{sm}$ & Obara, 1991 \\
\hline M. sibirica & 38 & 58 & $14 m+8 s m-s t+14 a$ & sm & - & Kurose et al., 2000 \\
\hline M. putorius & 40 & 64 & - & sm & $\mathrm{m}$ & $\begin{array}{l}\text { Graphodatsky et al., } \\
1976\end{array}$ \\
\hline M. nivalis nivalis & 42 & 74 & $10 \mathrm{~m}+24 \mathrm{sm}-\mathrm{st}+6 \mathrm{a}$ & $\mathrm{m}$ & $\mathrm{sm}$ & Obara, 1991 \\
\hline M. altaica & 44 & - & - & - & - & $\begin{array}{l}\text { Graphodatsky et al., } \\
1976\end{array}$ \\
\hline M. erminea orientalis & 44 & 64 & $6 \mathrm{~m}+16 \mathrm{sm}-\mathrm{st}+20 \mathrm{a}$ & $\mathrm{m}$ & st & Obara, 1991 \\
\hline Pteronura brasiliensis & 38 & 64 & $14 \mathrm{~m}+8 \mathrm{sm}+6 \mathrm{st}+8 \mathrm{a}$ & sm & $\mathrm{sm}$ & Present paper \\
\hline Vormela peregusna & 38 & 68 & $10 m+22 s m+4 a$ & sm & - & Ozkurt et al., 1999 \\
\hline
\end{tabular}

$\mathrm{a}=$ acrocentric, $\mathrm{m}=$ metacentric; $\mathrm{sm}=$ submetacentric; $\mathrm{st}=$ subtelocentric. A dash $(-)$ indicates that data is unavailable.

Our results show that the $P$. brasiliensis karyotype is very similar to the karyotype of the Japanese weasel, Mustela itatsi (Kurose et al., 2000), since both species present the same karyotypic formulae, a secondary constriction on the long arm of chromosome pair 17 and a submetacentric X chromosome. However, it is clear that the $P$. brasiliensis and $M$. itatsi karyotypes are species-specific since, among other factors, the $\mathrm{Y}$ chromosome is submetacentric in P. brasiliensis and acrocentric in M. itatsi.

The mustelids are also very diverse in regard to the C-banding pattern, with some presenting several heterochromatic short arms while others only show heterochromatic centromeric regions (Freitas et al., 1975; Kurose et al., 2000). We found that $P$. brasiliensis showed constitutive heterochromatin blocks at the centromeric region of all chromosomes and on the telomeric region of some of chro- mosomes. This pattern is totally different from that of the neotropical otter Lontra longicaudis which belongs to the same subfamily (Lutrinae) (Freitas et al., 1975).

The karyotype and chromosome constitution of the giant otter described in this paper could provide useful information to clarify the situation regarding the existence of the $P$. brasiliensis subspecies mentioned in the literature (Duplaix, 1980), if similar chromosomal studies are carried out with giant otters from the Pantanal region.

\section{Acknowledgments}

We thank MDV José Anselmo d'Affonseca Neto who conduct the anesthesia procedures and blood collection of the giant otters. We also thank Kesä K. Lehti for revision of the English in the first draft of the manuscript and Jorge Porto for the revision of the English in the final manuscript. 
This work was supported by the Brazilian agencies MCT/INPA, CNPq. J.F.O. Franco-de-Sá received undergraduate scholarships from PIBIC/CNPq/INPA.

\section{References}

Borobia M and Rosas FCW (1991) Sotalia fluviatilis, tucuxi (Gervais, 1853). In: Cappozzo HL and Junin M (eds) Estado de Conservación de los Mamíferos Marinos del Atlántico Sudoccidental. Informes y Estudios de Mares Regionales del PNUMA n. 138. Centro de Actividad del Programa para los Oceanos y Zonas Costeras del PNUMA, Nairobi, pp 36-41.

Carter SK and Rosas FCW (1997) Biology and conservation of the Giant Otter, Pteronura brasiliensis. Mammal Rev 27:1-26.

Couturier J and Dutrillaux B (1986) Évolution chromosomique chez les carnivores. Mammalia 50:124-162.

Duplaix N (1980) Observations on the ecology and behaviour of the giant otter Pteronura brasiliensis in Suriname. Rev Ecol 34:495-620.

Freitas TRO, Mattevi MS and Oliveira LFB (1975) Karyotype characterization of lontra (Lutra longicaudis longicaudis, Mustelidae, Carnivora). Mammalian Chromosomes Newsletter 23:91-96.

Graphodatsky AS, Volubuev V, Ternovsky D and Radjabli S (1976) G-banding patterns of sevenmustelid species (Mustelidae, Carnivora) in Russian. Zool Zh 55:1704-1709.

Graphodatsky AS, Yang F, Serdukova NA, Perelman PL, Zhdanova N and Ferguson-Smith MA (2000) Dog chromosomespecific paints reveal evolutionary inter-and intrachromosomal rearrangements in the American mink and human. Cytogenet Cell Genet 90:275-278.

Graphodatsky AS, Yang F, Perelman PL, O'Brien PCM, Serdukova NA, Milne BS, Biltueva LS, Fu B, Vorobieva NV, Kawada SI et al. (2002) Comparative molecular cytogenetic studies in the order Carnivora: Mapping chromosomal rearrangements onto the phylogenetic tree. Cytogenet Genome Res 96:1-4.

Guerra M (1988) Introdução à Citogenética Geral. Ed. Guanabara, Rio de Janeiro, 142 pp.
Howell WM and Black DA (1980) Controlled silver-staining of nucleolus organizer regions with a protective colloidal developer: A 1-step method. Experientia 36:1014-1015.

IUCN (2006) Red List of Threatened Species. IUCN, Gland, xviii $+61 \mathrm{pp}$.

Iwasa MA and Hosoda T (2002) A note on karyotype of the sable, Martes zibellina brachyura, in Hokkaido, Japan. Mammal Study 27:83-86.

Kurose N, Masuda R, Aor T and Watanabe S (2000) Karyological differentiation between two closely related mustelids, the Japanese weasel Mustela itatsi and the Siberian weasel Mustela siberica. Caryologia 53:269-275.

Levan A, Fredga K and Sandberg A (1964) Nomenclature for centromeric position on chromosomes. Hereditas 52:201220.

Macgregor HC (1993) An Introduction to Animal Cytogenetics. Chapman \& Hall, London, 238 pp.

Nie W, Wang J, O'Brien PCM, Fu B, Ying T, Ferguson-Smith MA and Yang F (2002) The genome phylogeny of domestic cat, red panda and five mustelid species revealed by comparative chromosome painting and G-banding. Chrom Res 10:209-222.

Nowak RM (1991) Walker's Mammals of the World. 5th ed. The Johns Hopkins University Press, Baltimore, 1629 pp.

Obara Y (1991) Karyosystematics of mustelid carnivores of Japan. Honyurui Kagaku. Mam Sci 30:197-220.

Ozkurt S, Sozen M, Yigit N and Çolak E (1999) A Study on Vormela peregusna, 1770 (Mammalia, Carnivora) in Turkey. Tr J Zool 23:141-144.

Rosas FCW (1994) Biology, conservation and status of the Amazonian Manatee Trichechus inunguis. Mammal Rev 24:4959.

Sumner AT (1972) A simple technique for demonstrating centromeric heterochromatin. Exp Cell Res 75:304-306.

Tsuchiya K (1979) A contribuition to the chromosome study in Japanese mammals. Proc Jp Acad Sci, Ser B 55:191-195.

Verma RS and Babu A (1995) Human Chromosomes: Principles and Techniques. McGraw-Hill, New York, 419 pp.

Yigit N, Çolak E, Sözen M and Özkurt S (1998) Contribution of the taxonomy, distribution and karyology of Martes foina (Erxleben, 1777) (Mammalia, Carnivora) in Turkey. Tr J Zool 22:297-301.

Associate Editor: Yatiyo Yonenaga-Yassuda 